\title{
The activities of older people when healthy ageing policy and funding is limited. The institutional and financial dimensions of Health Promotion for Odder People in Poland
}

\author{
Christoph Sowada ${ }^{1}$, Iwona Kowalska-Bobko ${ }^{1}$, Anna Mokrzycka ${ }^{1}$, \\ Alicja Domagała ${ }^{1}$, Agnieszka Sowa ${ }^{2}$, Michał Zabdyr-Jamróz', \\ Marzena Tambor ${ }^{1}$, Stanisława Golinowska ${ }^{1,2}$
}

\author{
${ }^{1}$ Institute of Public Health, Faculty of Health Sciences, Jagiellonian University Medical College, Cracow, Poland; \\ ${ }^{2}$ Department of Social Policy, Institute of Labour and Social Studies, Warsaw, Poland
}

Address for correspondence: Christoph Sowada, Jagiellonian University Medical College, Grzegórzecka 20 St., 30-351 Cracow, Poland, sowadach@poczta.onet.pl

\section{Abstract}

The presented country profile, based on several national reports, legal acts, international databases, scientific articles and pilot research performed with the use of health care sector templates, outlines the major institutional, organisational and financing challenges for health promotion in Poland, and specifically, health promotion for older adults.

Despite the numerous legislative and organisational changes in the health care sector since 1989 and the strengthening of the public health institutions in Poland, the country lacks a long-term, sustainable policy perspective in the public health area. The traditionally higher priority attached to curative care than to public health actions is one of the major reasons for the shortcomings of public health policy and the insufficient resources for health promotion and primary prevention in general, and health promotion for older adults specifically. However, there are also many weaknesses at the organisational level. One of the most important is the weak cooperation between the different levels of territorial self-government, the central government and other institutions when undertaking health promotion actions, which results in the development of both under- and overprovision of health promotion interventions for different population groups and at different geographical locations. Few self-government associations try to improve the cooperation and experience exchange in this field. However there is a need for a greater coordination and information exchange concerning plans and financial possibilities as well as for more competent health educators with better communication skills, less bureaucratic burdens, and better financial conditions.

\section{Key words: Health Promotion for Older People, public health, health expenditures, Poland}

\section{Introduction}

The objective of this Polish country profile in the area of health promotion for older people is collecting and presenting, in the standard report form, essential information on the organisation and funding of these activities in the context of the systemic arrangement of health care and public health. The institutional and financial description includes the primary institutions responsible for car- rying out tasks in this area - even if health promotion is just a fraction of their responsibility.

To give an overview of how health promotion is funded and organised both generally and specifically for older people we used desk research to identify relevant sources of information such as official national documents, legal acts, international databases and scientific articles. Additionally the pilot research performed in Poland with the use of health care sector templates helps to identify 
both: the main limitations and good practices concerning activities in health promotion for older people performed in the involved sectors. In our report we concentrate on three sectors: health, voluntary and territorial governance.

\section{Position of public health and health promotion in the health sector in Poland}

With the transformation of the political and economic system initiated in 1989, significant changes took place in the health care sector. Most notably, the budget financing of health care (Semashko model) was abandoned in favour of a quasi-insurance system (since 2004, a single payer system with National Health Fund/NFZ as the monopolistic insurer). The decision-making process has been decentralized and privatisation of the provision for as well as the financing of health care has begun [1].

The current total health expenditure in Poland accounted for $6.4 \%$ of GDP in 2015 . The level of resources allocated to health has been steadily increasing (see Table I). During the period of 2000-2015 the real current health expenditure per capita (base year 2005) has nearly doubled. Approximately $70 \%$ of the expenditure comes from public sources (largely from health insurance contributions). Private expenditure includes mostly out-ofpocket payments. Households' out-of-pocket expenditure as a share of the total health expenditure is approximately $23 \%$. A vast majority of health resources $(95 \%)$ is devoted to finance individual health care services. The expenditure on collective health care accounts for about $5 \%$ of the total current health expenditure, and approximately half of these resources are spent on prevention and public health services.

The turning away from the Semashko model affected the sphere of health promotion and disease prevention which, as in other countries, are grouped primarily, but not exclusively, within the health care system. Therefore, most legislative regulations concerning health promotion are acts adopted in different areas of health care (see Box 1). There are also different so-called local government acts which define the organisational and financial responsibilities of territorial government bodies in the area of health promotion. Bearing in mind the implementation of the many and varied tasks related to health promotion, the Law on public benefit and volunteer activities as well the Law on the National Sanitary Inspectorate can also be considered crucial legal acts.

New state agencies, including the Departments of Health Promotion in the structures of Provincial Public Health Centres, were established. The existing institutions, such as the State Sanitary Inspection, and various research and educational institutes (e.g. the National Institute of Public Health - the National Institute of Hygiene in Warsaw, the Nofer Institute of Occupational Medicine in Lódź, the Central Institute for Labour Protection - the National Research Institute) intensified their activities and broadened the scope of their healthrelated initiatives. From the other side, new social organisations came into play, with statutory missions of managing prevention, health promotion and health education activities (e.g. the Polish Society for Health Education in 1993).

A new impulse for fostering health promotion ideas in Poland is expected to come from the Law on public health of 11 September 2015. Among other tasks it lists health education, health promotion and disease prevention tailored to different groups of the population, including the growing group of older people (see Box 2) with their specific health status and health needs (see Box 3). It also organises, to some extent, provisions concerning the responsibility of public and private institutions at various levels for the implementation and financing of the tasks in the field of public health, including health promotion and health education.

\begin{tabular}{|l|c|c|c|c|c|c|c|}
\hline & 2000 & 2005 & 2007 & 2010 & $\begin{array}{c}2015 \\
\text { (or the latest) }\end{array}$ & $\begin{array}{c}\text { Change 2000 } \\
\text { to 2015 }\end{array}$ & $\begin{array}{c}\text { Change 2007 } \\
\text { to 2015 }\end{array}$ \\
\hline $\begin{array}{l}\text { Current health expenditure per } \\
\text { capita, constant prices OECD } \\
\text { base year 2010 in zloty }\end{array}$ & 1364.0 & 1755.6 & 2013.6 & 2438.7 & 2779.2 & $+103.75 \%$ & $+38.0 \%$ \\
\hline $\begin{array}{l}\text { Current health expenditure as } \\
\text { \% of GDP }\end{array}$ & 5.3 & 5.8 & 5.9 & 6.5 & 6.4 & +1.1 & +0.5 \\
\hline $\begin{array}{l}\text { Share of general government } \\
\text { in current health expenditures }\end{array}$ & 68.9 & 68.7 & 70.1 & 71.7 & 71.6 & +2.7 & +1.5 \\
\hline $\begin{array}{l}\text { Share of individual health care } \\
\text { services and medical goods in } \\
\text { expenditure on health }\end{array}$ & - & 96.0 & 95.5 & 96.5 & 95.2 & & \\
\hline $\begin{array}{l}\text { Share of prevention and public } \\
\text { health services in current } \\
\text { expenditure on health }\end{array}$ & - & 2.4 & 2.4 & 2.1 & 2.6 & & \\
\hline
\end{tabular}

Table I. Health system indicators. 
Law on Therapeutic Activity dated 15 April 2011, dated 15 April 2011 (Journal of Laws 2011, No. 112, Item 654, as amended)

- Law on Health Care Services Financed from Public Sources, dated 27 August 2004 (Journal of Laws 2004, No. 210, Item 2135, as amended)

- Law on local self-government, dated 8 March 1990 (Journal of Laws 1990, No. 16, Item 95, as amended)

- Law on powiat* self-government, dated 5 June 1998 (Journal of Laws 1998, No. 91, Item 578, as amended)

- Law on voivodeship* self-government, dated 5 June 1998 (Journal of Laws 1998, No. 91, Item 576, as amended)

- Law on the National Sanitary Inspectorate, dated 14 March 1985 (Journal of Laws 1985, No. 12, Item 49, as amended)

- Law on public benefit and volunteer activities, dated 24 April 2003 (Journal of Laws 2003, No. 96, Item 873, as amended)

- Law on public health, dated 11 September 2015 (Journal of Laws 2015, Item 1916 as amended)

- Law on Education in Sobriety and Prevention of Alcoholism, dated 26 October 1982 (Journal of Laws 2015, Item 230 as amended)

- Ministry of health regulation on guaranteed primary care health services, dated 24 September 2013 (Journal of Laws 2013, Item 1248)

- Decree No 85/2011/DSOZ of the National Health Fund President (dated 17 November 2011) on the conditions for arrangements and realisation of contracts for health service delivery: primary care type

- Decree No 98/2012/DSOZ of the National Health Fund President (dated 21 January 2012) on the conditions for arrangements and realisation of contracts for health service delivery: Prophylaxis health programmes

* The Polish territorial self-government has been divided into three levels: regions (voivodship), counties (powiat) and municipalities (gmina).

Box 1. Main legal acts concerning public health and health promotion issues.

Source: Authors'own presentation.

Poland is still a relatively young European country, with $11.4 \%$ of the population aged 65 to 79 and $4.0 \%$ of the population above 80 years of age, which is below the average of the EU-28 (13.6\% and 5.3\% of the population respectively) in 2015. The average life expectancy (LE) at birth has been increasing over the past two decades, amounting to 81.7 years for females and 73.7 years for males in 2014 (the EU-28 average is 83.6 for females and 78.1 for males). The healthy life years are estimated as 62.7 for females and for male as 59.8 (in 2014) which means that, on average, women might expect to spend about $77 \%$ of their lives in good health and without disability and men about $81 \%$. The life expectancy at the age of 65 amounts to 20.4 years for females, and about $39 \%$ of life in older age is expected to be spent in good health and without disability. For males the life expectancy at the age of 65 amounts to 15.9 years and about $45 \%$ is estimated to be spent healthily. Due to the increase in life expectancy and the low fertility rate, the share of people 65+ in Poland is foreseen to raise from $14.9 \%$ in 2014 to $32.9 \%$ in 2060 . At the same time, the proportion of the oldest old $(80+)$ will triple, amounting to $12 \%$ of the total population in 2060 . This demographic trend will result in an increase in the old age dependency ${ }^{1}$ ratio from 21.8 in 2015 to 60.9 in 2060.

Box 2. Population ageing indicators.

Source: Based on Eurostat data, http://ec.europa.eu/eurostat/data/database; accessed: 14.10.2016.

The health status of the older population is characterized by living with different illnesses, often coexisting and in many cases chronic. It is assessed based on objective indicators such as mortality as well as subjective indicators of perceived health, reported morbidity, chronic conditions and functional capacities.

Male mortality from all causes at the age of $65+(5,476 / 100,000$ population in 2014) in Poland is much higher than female $(3,341 / 100,000$ in 2014). The main causes of mortality are cardiovascular diseases, constituting $47 \%$ of all deaths for men $(2,574 / 100,000)$ and $53 \%$ of all deaths for women $(1,780 / 100,000)$. The second cause of mortality are cancers, accounting for $27 \%$ of all deaths for men $(1,486 / 100,000)$ and $22 \%$ of all deaths for women $(747 / 100,000)$. Respiratory system diseases constitute $8 \%$ of male deaths $(400 / 100,000)$ and $5 \%$ for women $(169 / 100,000)$. The self assessed health status of older people is poor, although it has slightly improved over recent years. $65 \%$ of people aged $60-69,79 \%$ of people aged $70-79$ and $88 \%$ of people above 80 years of age assessed their health status as worse than good in 2014 [2]. More than $85 \%$ of people aged $60+$ reported suffering from long-term illness and at the age of $80+$ this share rose to $90 \%$. The main chronic conditions of older people are cardiovascular system diseases, pulmonary diseases, diabetes, osteoporosis and arthritis, vision and hearing impairments and cognitive disorders. According to the POLSENIOR hypertension is observed in $77 \%$ of men/79\% of females aged $65-79$ and $66 \%$ of men $/ 76 \%$ of females age $80+$ [3]. Over $50 \%$ of people aged $65+$ have moderate vision problems and over $30 \%$ have hearing problems. $40 \%$ of the population $65+$ suffers from diabetes and in half of the cases this condition has not been recognized and adequately treated. Dementia is reported in about $1.3 \%$ of the total population, but some sort of cognitive impairments are observed in as much as $60 \%$ of older people $(65+)$. About one third of older people suffer from moderate depression [3].

Older age is characterized by a loss of functional capabilities. Long standing limitations in everyday activities are reported by $44.6 \%$ of men $/ 46.3 \%$ of women aged $65-74$ and increases to $69.3 \%$ of men/79.1\% of women above 85 years of age in 2014 .

The main behavioural risk factors for poor health and occurrence of functional limitations include inadequate nutrition, smoking and falls. According to the European Health Interview Survey of $2009,28 \%$ of people aged $60-69$ suffered from obesity (BMI $\geq 30$ ) and this share decreased to $18 \%$ above the age of $80 ; 25 \%$ of people aged $60-69$ smoked cigarettes and this share decreased to less the $5 \%$ at the age of 80 [4] The reported incidence rate (falls) per 100000 population accounts to $62.4 / 100,000$ for the population $65+$.

\section{Box 3. Health status of older population}

Source: Based on European health for all database (HFA-DB) WHO Regional Office for Europe, http://data.euro.who.int/hfadb/; accessed: 02.04.2016; Alzheimer Europe, http://www.alzheimer-europe.org/Policy-in-Practice2/Country-comparisons/The-prevalence-of-dementia-in-Europe/Poland; accessed: 02.04.2016; Eurostat, EU-SILC data http://ec.europa.eu/eurostat/data/database; accessed: 30.06.2015; Eupha, https://eupha.org/repository/sections/ipsp/Factsheet_falls_in_older_adults_in_EU.pdf; accessed: 14.10.2016. 
The Law on public health establishes the National Health Programme as the most important document and tool for implementing public health policy. The first such programme was scheduled for the years 1996-2005 and the second for 2007-2015. The new one for 20162020 has been passed by the Polish government on $16^{\text {th }}$ September 2016. Last but not least, the law mandates the NHF to allocate at least $1.5 \%$ of their total expenditure to health care costs for health promotion and disease prevention, including the funding of health policy programmes.

\section{Funding of Public Health and Health Promotion - potential sources and main institutions}

The diversity of organisations performing health promotion tasks combined with the lack of an institutional separation of health promotion and the significant degree of fragmentation of health promotion activities makes it challenging to identify the real sources of funding, both public and private. At the central government (macro) level, the Polish statistics show only aggregated numbers - expenditures for public health and prevention. Three fundamental sources of data on health expenditures, i.e. state and local governments' budget reports, the National Health Fund reports, and prepared on their basis, the Central Statistical Office (GUS) reports, use different methodologies for calculating costs and different classifications of institutions. The most general methodology of the GUS, based on a system of National Health Accounts (NHA, see Table II), does not list health pro- motion as a separate position. It shows the expenditure on preventive health care and public health, which does not cover the total spending on health promotion because some spending is included in the expenditure on health services, e.g. the part of the capitation rates of the primary health care providers that covers the costs of health promotion activities carried out by them. As a result, the figures presented at the end of this chapter should be treated with caution as they are more an estimation of the order of magnitude rather than a precise calculation of expenses.

The GUS also publishes data, based on budgetary reporting, on the state and the local government's expenditure on activities related to health promotion, e.g. health inspection, health policy programmes, combating alcoholism and drug addiction. The NFZ reports an item listed as 'Costs of preventive health programmes and health policy programmes financed from NFZ funds' that includes expenditures for: General programme for early breast cancer detection, Cervical cancer prevention programme, Tuberculosis prevention programme, Prenatal screening programme, Prevention of cardiovascular diseases, and Prevention programme for tobaccorelated diseases (including COPD) [5]. Although these programmes contain elements that could be included in the area of health promotion and health education, they focus on prevention programmes for early detection of diseases through relatively extensive screening. The institutions involved in activities promoting health and health education include, not only public authorities at various levels and health care providers, but also a num-

\begin{tabular}{|l|l|l|}
\hline HC.6.1 & $\begin{array}{l}\text { Maternal and child health, } \\
\text { family planning and family } \\
\text { counselling }\end{array}$ & $\begin{array}{l}\text { Ministry of Health: } \\
- \text { health policy programmes (comprehensive intrauterine diagnosis and therapy programme } \\
\text { in the prevention of complications resulting from diseases and fetal malformations) } \\
\text { - health insurance premiums for those not obliged to be covered under health insurance } \\
\text { (e.g. pregnancy and childbirth-related benefits) }\end{array}$ \\
\hline HC.6.2 & School-based medical care & National Health Fund: primary health care in schools \\
\hline HC.6.3 & $\begin{array}{l}\text { Prevention of infectious } \\
\text { diseases }\end{array}$ & $\begin{array}{l}\text { Ministry of Health: } \\
\text { - health policy programmes (Immunization Programme) } \\
\text { - prevention and fighting AIDS (prevention programmes, National Centre for AIDS) } \\
\text { Local government units: } \\
\text { - prevention and fighting AIDS (prevention programmes) }\end{array}$ \\
\hline HC.6.4 & $\begin{array}{l}\text { Prevention of non-communi- } \\
\text { cable diseases }\end{array}$ & $\begin{array}{l}\text { Ministry of Health: health policy programmes } \\
\text { National Health Fund: the costs of prevention programmes } \\
\text { Local government units: combating drug addiction, counteracting alcoholism, detoxification } \\
\text { detention centres }\end{array}$ \\
\hline HC.6.5 & $\begin{array}{l}\text { Occupational medicine } \\
\text { HC.6.9 }\end{array}$ & $\begin{array}{l}\text { Ministry of Health and local government units: occupational medicine } \\
\text { Ministry of Justice: expenditure on research for prisoners } \\
\text { Private: estimated expenses of the employers on occupational medicine }\end{array}$ \\
\hline $\begin{array}{l}\text { Other services in the field of } \\
\text { and management of blood and } \\
\text { organ banks) }\end{array}$ & $\begin{array}{l}\text { Ministry of Health: health policy programmes (ensuring Poland's self-sufficiency in blood } \\
\text { and its components, a programme for the elimination of iodine deficiency in Poland, national } \\
\text { programme for the development of transplantation medicine) } \\
\text { Local government units: health policy programmes, public blood service } \\
\text { Private: NGO activity in the field of public health }\end{array}$ \\
\hline
\end{tabular}

Table II. Classification of expenditure on prevention and public health according to the NHA classification and corresponding expenses in Poland.

Source: Based on OECD Health Statistics 2015 Description of Sources and Methods - Poland. 
ber of other entities such as public benefit organisations and foundations (NGOs), semi-formal social initiatives, businesses, religious associations and churches, schools and universities, research institutes, individuals and foreign entities. This abundance of entities is accompanied by a variety of potential sources of funding, both public and private, with financial flows that are equally diverse (see Table III). Public funds go not only to public institutions but also, through grants and subsidies, to private entities performing tasks related to health promotion, education, and preventive health care. Public institutions in turn benefit on a large scale from the financial aid of private benefactors.

The estimates of the GUS drawn up as part of the NHA show that the expenditure on prevention and public health in Poland in 2013 represented $2.57 \%$ of the total expenditure on health (approx. PLN 2.7 bn, Table I [6]).
Compared to 2012, there was a significant increase in the total expenditure on prevention and public health by over 30\% (from PLN 2 bn) and in the share of the total current expenditure by half of a percentage point (from $2 \%$ ). However, as already noted, due to the variety of activities that fall within the scope of public health, the expenditure on tasks related to public health including health promotion can also be listed as part of administrative expenditure, expenditure on medical services, or under functions related to health care, which include, among others: education and training of medical staff, research and development in health care or food, hygiene and drinking water control.

The NHA estimates indicate that public spending (including the state budget, local government budgets and the National Health Fund) in 2013 accounted for almost $73 \%$ of total expenditure on prevention and public health

\begin{tabular}{|c|c|c|}
\hline Source of funding & Beneficiary & Comments \\
\hline General taxation & $\begin{array}{l}\text { Central government institutions: } \\
\text { - Central offices } \\
\text { - The State Sanitary Inspection } \\
\text { - Local government bodies - for the implementation of assigned tasks } \\
\text { - National research institutes (e.g. the National Public Health Institute and } \\
\text { the National Hygiene Institute, the Nofer Institute of Occupational Me- } \\
\text { dicine in Łódź, the Central Institute of Labour Protection, the Institute } \\
\text { of Rural Medicine in Lublin, the Institute of Occupational Medicine and } \\
\text { Environmental Health in Sosnowiec) } \\
\text { - Health care providers implementing the central/national health program- } \\
\text { mes* } \\
\text { - NGOs** }\end{array}$ & $\begin{array}{l}* \text { Contracting of health care services } \\
\text { through the National Health Fund } \\
* * \text { NGOs through grants and subsidies }\end{array}$ \\
\hline $\begin{array}{l}\text { Local taxes and } \\
\text { fees }\end{array}$ & $\begin{array}{l}\text { - Local government bodies - for the implementation of their own manda- } \\
\text { tory tasks } \\
\text { - Local initiatives } \\
\text { - Schools and other educational and care facilities } \\
\text { - NGOs* } \\
\text { - Health care providers** }\end{array}$ & $\begin{array}{l}\text { * NGOs through grants and subsidies } \\
\text { ** for the implementation of tasks assig- } \\
\text { ned by the local government - usually for } \\
\text { the entities in which the local government } \\
\text { is the founding body }\end{array}$ \\
\hline $\begin{array}{l}\text { Health insurance } \\
\text { premiums }\end{array}$ & $\begin{array}{l}\text { - Primary health care providers within capitation rates } \\
\text { - Health care providers implementing their own NHF health programmes }\end{array}$ & \\
\hline $\begin{array}{l}\text { Funds from the } \\
\text { employers }\end{array}$ & $\begin{array}{l}\text { - } \text { Bodies carrying out tasks in the area of occupational medicine } \\
\text { - Private initiatives/NGOs* } \\
\text { - Local communities' initiatives* } \\
\text { - Churches and religious associations* }\end{array}$ & * funding/sponsoring \\
\hline $\begin{array}{l}\text { Business opera- } \\
\text { tions* }\end{array}$ & $\begin{array}{l}\text { - Institutes } \\
\text { - Private initiatives/NGOs } \\
\text { - Local communities' initiatives }\end{array}$ & $\begin{array}{l}\text { * research institutes, NGOs/local initia- } \\
\text { tives: organising meetings, conferences/ } \\
\text { festivals, publishing, providing services }\end{array}$ \\
\hline Households & $\begin{array}{l}\text { - Health care providers* } \\
\text { - } \text { NGOs/Associations** }\end{array}$ & $\begin{array}{l}* \text { charges } \\
* * \text { membership fees, donations, legacies }\end{array}$ \\
\hline Foundations* & $\begin{array}{l}\text { - } \text { Health care providers } \\
\text { - NGOs/Associations } \\
\text { - Local initiatives } \\
\text { - } \quad \text { Third age universities }\end{array}$ & $\begin{array}{l}\text { * e.g. the Polish-American Freedom } \\
\text { Foundation, university foundations }\end{array}$ \\
\hline Foreign* & $\begin{array}{l}\text { Grant beneficiaries - research institutes, health care providers, schools and } \\
\text { colleges, NGOs, local initiatives }\end{array}$ & $\begin{array}{l}\text { * European funds, Norwegian and Swiss } \\
\text { funds, the World Health Organization, } \\
\text { European associations (e.g. the European } \\
\text { Healthy Cities Network), foreign house- } \\
\text { holds }\end{array}$ \\
\hline
\end{tabular}

Table III. Potential sources for Health Promotion.

Source: Authors'own presentation. 
(less than PLN 2 bn), which corresponds to the structure of total expenditure on health in Poland, in which public funds also constitute a 70 percent share. However, as opposed to health care (curative medicine), most public health funding does not come from health insurance contributions but from taxation revenues that remain at the disposal of the state budget and territorial self-government units. The spending on health care from the state budget (approx. PLN 7.4 bn in total in 2014) includes significant expenditure on sanitary inspections (which also includes the salaries of the Sanitary Inspectorate staff) and health policy programmes, financed mainly with the Ministry of Health's own funds (Table IV). An important position in the expenditure of territorial self-governments for health (total approx. PLN 3.7 bn in 2014 ) is the spending on alcoholism prevention (approx. PLN 700 million), managed primarily by the local governments. Territorial self-government expenditures on health policy programmes in 2014 amounted to approx.
PLN 67 million, which represents $1.8 \%$ of their total expenditure on health (Table IV).

The Law on public health from 2015 puts an obligation on the NFZ to allocate in the future no less than $1.5 \%$ of total expenditure on health care services to the funding of prevention and health promotion programmes. Achieving this threshold may present quite a challenge given the fact that in recent years, the spending averaged below $0.3 \%$. The NFZ finances mostly prevention programmes (mentioned above), which amounts to approx. PLN 169.0 million, nearly $0.3 \%$ of the total NFZ expenditure in 2015 [5]. Most of these expenses are incurred on the basis of separately concluded contracts with health service providers (hospitals, practices, doctors and nurses). However, it should be emphasised once more that the presented numbers do not show the engagement of the NFZ in health promotion funding implemented within the framework of the regular contracts concluded with primary health care units.

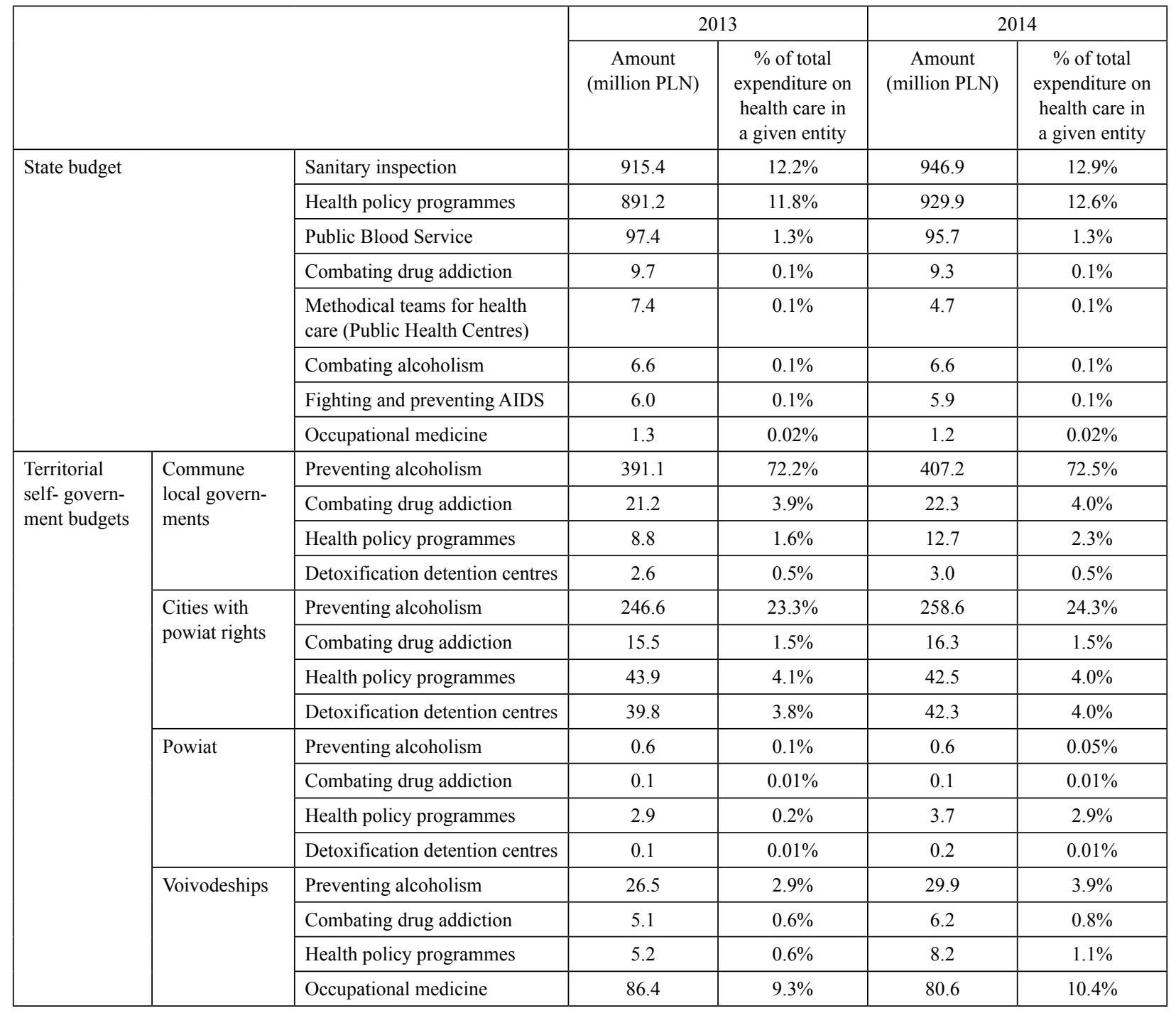

Expenditure of local governments including funds received from the state budget (i.e. expenses without eliminating transfers between entities).

Table IV. State budget and local government units' expenditure on public health tasks for 2013-2014.

Source: Based on GUS [6]. 
According to the GUS reporting, private spending on prevention and public health in 2013 amounted to PLN 741.1 million, which was about 115 million (18\%) more than in 2012. More than $80 \%$ (PLN 613.5 million) of this amount was provided by businesses. Given the fact that these funds have been fully used by health care facilities, it can be concluded that the expenses were related to occupational medicine. The rest of the private resources came from non-profit institutions. These funds were fully used by preventive health service providers.

\section{Organisation and financing of health promotion interventions for older adullts}

As mentioned above the diversity of tasks in health promotion and in organisations performing these tasks, makes it challenging to identify the real sources of funding. There are no separate aggregated data on expenditures for health promotion activities, not to mention data on funding of health promotion for older people. What we can try to do is to identify concrete programmes provided in different sectors by different institutions and organisations to show their funding sources and used mechanism. In Poland three sectors seem to play a major role in providing health promotion interventions for older people: the sector of local governments and municipalities, the voluntary sector and the health sector.

\subsection{Health promotion for older people performed by local governments}

\section{Role of regional and local self-government in Health Promotion for Older People}

Since 1999, Polish territorial self-government has been divided into three levels: 16 regions (voivodships), 380 counties (powiat) $)^{2}$ and 2,412 municipalities (gmina) which perform public tasks not exclusively reserved for public authorities at higher levels. In the area of health care, territorial self-governments are mainly responsible for health promotion and prevention, and for tasks related to their function as the proprietors of public health care units. According to the Law on health care services financed from public sources, local governments are obliged to plan, implement and evaluate health programmes addressing diagnosed local health needs.

Several forms of local governmental activity apply to the issue of health promotion for older people. This applies to the development of local health care systems, including the development and implementation of community health promotion and prevention programmes (impact raising public awareness in the field of "healthy ageing," the promotion of a healthy lifestyle, etc.). Local government units work to create opportunities to facilitate increased access to diagnosis and treatment, support the implementation of screening programmes, and promote early diagnosis. At the regional and local levels it is becoming important to create favourable conditions for dignified ageing. Regional and local authorities are often involved in the modernisation and construction of infrastructure facilities for older people. Local governments also prioritise the development and support (also financial) of various initiatives dedicated to the elderly undertaken by NGOs (e.g. continuing education, stimulating physical activities, a healthy lifestyle, etc). At the lowest local municipality level Senior representatives Senior councils - are actively involved in planning local programmes for the elderly. The local governments also play an important role in establishing wider social policy and are very often the creator of the education activities for the elderly.

\section{Cooperation of the different levels of territorial self-government and the central government institution}

Each level of territorial self-government is independent - it has its own organisational units and responsibilities. Territorial self-governments are run by political parties and lobby for their own territorial issues. This makes the coordination of activities and an effective use of financial resources (coming from different budgets) difficult [7]. The cooperation of the different levels of territorial self-government in the sphere of health promotion programmes is difficult as well. On one side, there is a lack of knowledge concerning central governmental programmes on the activation of the older population and on the other side, there are many difficulties in relation to the central government and territorial self-governments, such as direct conflict, a lack of partnership and cooperation, which make the coordination of their activities challenging. Weak cooperation among different levels of territorial self-governmental units, the central government, and national agencies (e.g. the National Health Fund, the Chief National Sanitary Inspectorate) is one of the key problems in the implementation of community health promotion programmes. Objectives and target groups of programmes realised by different institutions in the same geographical area are sometimes duplicated even if there are a few very active and supportive self-government associations oriented towards improving cooperation and sharing experience: The Federation of Polish Municipalities (Zwiazek Miast Polskich), The Association of Polish Counties (Zwiazek Powiatów Polskich) and The Association of Polish Healthy Cities (Stowarzyszenie Zdrowych Miast Polskich). Thus there is a need to provide a reliable source of information concerning realised and planned health programmes as well as their outcomes at the regional and local levels.

\section{Cooperation with other sectors and institutions}

The local government's main goals are developing and supporting various initiatives, including those undertaken by non-governmental organisations, such as continuing education, promoting physical culture, tourist associations and others. These organisations, often supported by local and regional authorities, activate older people and promote cooperation in a very professional way, at the same time taking care of their health and intellectual prowess. Territorial self-governments usually organise competitions and deliver organisational and financial support for the best proposals of the programmes. 
Financing community health promotion programmes

The realisation of health programmes is a statutorily obligatory task of all local government levels in Poland. The practical aspects of this task are however highly dependent on several factors including: organisational and financial restrictions, the availability of supporting tools and the adequate competencies of local governments representatives. Community health promotion and prevention programmes are mainly funded by their own-sources. Regional and local self-governments can also apply for financial support from national and international financial sources:

- financial sources from the educational sector and the sport sector;

- Operational Programme - Infrastructure and Environment;

- Swiss Contribution Programme

- EOG Funds and Norway Grants;

- National operational projects funded by European Union funds.

Polish regional and local self-governments have no legal possibility to apply for funding of their health programmes by the National Health Fund.

\section{Examples of public programmes and good practices}

A few Polish self-governments (especially big cities) are very active in the field of health promotion for older people and provide their own programmes. One interesting programme - "The Development Strategy for the Opolskie Voivodship until 2020" - was developed by the Marshal Office in Opole. Its most important portion "Golden Autumn" - is aimed at improving the quality and availability of services for older people, increasing the activity of the elderly and improving the digital competency of citizens $50+{ }^{5}$

The Municipality of Sopot is a member of the international programme, "SENIOR CAPITAL" (Develop the human capital of seniors to increase their economic and social value in a knowledge based and competitive economy), which is a follow-up of the former project, "Quality Ageing in an Urban Environment" ("Q-AGEING"). ${ }^{6}$ Within this project the Municipality of Sopot has developed a strategic approach to documenting urban barriers and to taking them into consideration when infrastructural developments are made in future (The Urban Barrier Map). On one hand, this Map is a digital database, containing information about the architectural barriers of the city. Secondly, it is a real map, with a photo-documentation about the barriers. It is editable, so the municipality can add new records in case new barriers are identified in future or to delete barriers that have been removed. For the municipality this Urban Barrier Map can be used as the basis for development of future infrastructural projects.

The Municipality of Krakow implemented the PASIOS (Programme for social activity and integration of older people) programme for social activity and the integration of older people in the city. Another programme, "The Golden Age," is focused on educational activities and preventing an unhealthy lifestyle in order to reduce the number of people who will require residential care in the future. The target groups of this project are: physicians and nurses (as participants of special trainings), the elderly and their family. The project's activities are oriented towards prevention of diseases associated with lifestyle and promotion of "healthy ageing." Moreover the Municipality of Krakow is a member of the "Innovation for the Creation of Conditions Friendly to All Age Groups" programme, developed by the European Platform of Senior Organisations - AGE (AGE Platform Europe) 2013-2016 and the "Demographic Change Pact" - an initiative linking European local, regional and national governments, as well as other interested parties that declare cooperation in the implementation of innovative solutions supporting active and healthy ageing.

The regional and local governments in Poland can provide their own programmes, but in many cases are also obliged to implement national programmes. The main governmental initiatives in the field of health promotion for older adults which are implemented by the regional and local self-government units are:

a) Programme for Social Participation of Senior Citizens (ASOS), addressed directly at supporting actions - projects (based on priorities: education, integration promoting solidarity between generations, social participation and services for older citizens as a key element of active ageing) by the organisations that operate in the area of public benefit for senior citizens;

b) The Long Term Senior Policy in Poland 2014-2020 (LTSP) (as a follow up of the ASOS Programme adopted by the Polish Government in December $2013^{9}$ );

c) A programme called "Senior - Wigor" 10 , started by the Ministry of Labour and Social Policy. This programme will be carried out from the years 20152020 and will include all voivodships. Once the local government unit receives funds for the programme, it is obliged to carry out the programme for at least 5 years. Under the programme, local governments are obliged to organize day care/activation centres as a place for the meetings of the elderly $60+$ (offering various forms of activities like: educational courses, sports exercises, rehabilitation, dance and others).

\section{Main limitations and barriers in planning and im- plementing public health promotion programmes for older people}

Beyond the financial and coordination problems, the lack of professionals poses a particular challenge for the planning and implementing of community health promotion programmes. All programmes must be submitted to The Agency for Health Technology Assessment and Tariff System (AOTMiT), which conducts an appraisal process. The Agency issues an opinion (positive or negative) which includes suggestions for corrections to the programmes' projects. Many programmes submitted to the Agency are not well prepared. The analysis of the opinions' texts reveals the most common problems: an 
unclear description of programme objectives, a lack of a precise description of the programme's expected outcomes (which consequently hinders the monitoring and evaluation process), inadequate information on the programme's financing sources, the lack of a programme budget (which makes it impossible to assess the programme's cost-effectiveness) and the lack of relation to local epidemiological data.

In the area of the social participation of senior citizens, the main focus must be put on education as well as volunteering, civic engagement and participation in culture. A significant barrier is the willingness to participate in the programmes offered by self-governments. Therefore, it is important to establish wider promotion of all possible channels to reach potential customers for both active seniors and younger generations. Intergenerational relations are also an important goal of senior policy. However the most urgent challenge within ageing societies is putting conditions for healthy ageing in place. To achieve this target, various stakeholders must be involved (including social partners and NGOs, as well as citizens themselves).

\subsection{Health promotion for older people performedl and provided by the voluntary sector}

\section{Role of voluntary sector in health promotion for older people}

After only a quarter century of democratic government, civil society in Poland is still in development. According to the most recent data, 19\% of Poles declare that they have spent their free time in voluntary non-payed work for some form of organisation [9]. Nevertheless in 2015, there were circa 103,000 NGOs registered in Poland - 17,000 foundations and 86,000 associations. ${ }^{11}$ However, only 70,000 of them remain active. NGOs that fulfil certain requirements, primarily performing their enumerated goals, as well as entities that are not legally classified as NGOs, can apply for the status of Public Benefit Organisations (PBO). Out of the entirety of NGOs, 8,033 enjoy this status. ${ }^{12}$

In 2015, 2,484 NGOs declared themselves as being active "for the benefit of retirement-age persons". About 200 NGOs with the status of Public Benefit Organisation operate for the benefit of older people as their primary or supplementary activity. ${ }^{13}$ The main institution responsible for the cooperation of the government with the NGO sector is the Ministry of Family, Labour and Social Policy (MRPiPS ${ }^{14}$ ) - the same one that is responsible for policy programmes oriented towards health promotion for the older population.

The main activities in the field of health promotion for older people within the voluntary sector fall into several categories: social engagement and self-support or providing healthy activities (sport, recreation, tourism, travel) as well as health information, education and marketing. Often NGOs also organise health screenings and diseases prevention with assistance from other sectors.

Based on the level of financial support, the most significant role is played by those PBOs that perform public tasks delegated and financed by governmental institutions (both central and local). This includes the central initiatives mentioned above, such as the ASOS Programme and the Senior-WIGOR Programme. There are also local programmes such as the PASIOS programme in Kraków which delegates to NGOs the organisation and management of Senior Activity Centres. Another noteworthy field are Universities of the Third Age that serve from 100,000 to 160,000 learners per year with 320 learners per institution [10, 11]. In this area Poland is considered among the leaders in the world, providing experience for even western-European countries, even though these institutions are not legally regulated in any special manner. According to the data of March 2015, there are over 500 such institutions in Poland and this number is systematically growing from about 300 in 2011 and 400 in 2012.

Another relevant category of NGO institutions which traditionally plays a significant role in providing fresh-air physical activity and recreation for older people living in cities - especially those of retirement age are Family Allotment Gardens. It should also be noted that among the voluntary activities in Poland, religious institutions (most notably the Catholic Church) play an important role in the social activation of older people. These take varying forms, from the "rosary circles"- informal prayer groups - to organised pilgrimages to places of worship (also abroad). They are largely based on voluntary work of their participants and provide social activation and interaction and self-help as well as recreation and physical activity [12]. Church-based institutions can also acquire PBO status and apply for recognition in the performance of public tasks.

\section{Cooperation of $\mathrm{NGO}$ s with other sectors}

Public resources - especially those received from territorial self-governments - remain the main source of income for NGOs in Poland. Overall, the declared level of cooperation with organisations from other sectors (local self-governments: $92 \%$, local communities: $89 \%$, local media: $89 \%$, companies: $75 \%$ ) as well as within the sector $(92 \%)$ is very high and it is growing. The problem is, however, the sustainability of such cooperation [1315]. Increased cooperation between NGOs and business enterprises is being observed. However, it is mostly of a non-financial character; thus, it does not translate into increased donations.

\section{Financing of NGOs}

It is an increasingly common practice that NGOs with PBO status perform delegated public tasks. The subsidies for those duties as well as other grants from the central and local governments are a significant and growing source of income for NGOs. $60 \%$ of NGOs receive them. On the other hand, donations by individuals and companies are decreasing. The income from membership fees is insufficient and the fees for services (such as in case of Universities of the Third Age) discourage participation [13-15]. The external financing for Universities of the Third Age comes - through the Ministry of [Family], Labour and Social Affairs - from the Fund for Citizens' 
Initiatives (FIO, Fundusz Inicjatyw Obywatelskich) and from the Polish-American Freedom Foundation as well as from the Grundtvig European Commission Programme and the European Social Fund.

\section{Examples of programmes in the voluntary sector}

The expertise in the activities of NGOs comes from various sources as shown in the healthProElderly study, which indicated several older Polish health promotion programmes from the 1990s addressed towards the older population [16]. But there are also several more current initiatives that potentially could be indicated as good practices in the sector. The MANKO Association, ${ }^{15}$ for instance, received a training from the Johns Hopkins Bloomberg School of Public Health, which was financed by Mike Bloomberg's Philanthropies. Also, for the consultation of ongoing activities, MANKO created a Council of Experts within "Senior's Voice" magazine (Gtos Seniora Portal Nowoczesnego Seniora ${ }^{16}$ ). It is composed of specialists and practitioners from universities and various organisations, as well as some parliament members. Also, other initiatives of the MANKO Association performed in collaboration with multiple organisations from other sectors: Senioriada and Senior's Days, local events that involve educational actions (lectures) and health screening opportunities, are performed together with the health sector. A discount "Nationwide Senior's Card" is issued in collaboration with various enterprises as well as health care providers ${ }^{17}$.

Another interesting initiative comes from the Organisation "Forum 50+ Seniors of the XXI century", an independent coalition of 22 NGOs that has been in operation since 2011 and that works primarily as an advocacy organisation for the interests of older people. ${ }^{18}$ Interestingly, it was an NGO - the ProEthica Association - that developed a Model of social services for the elderly within the central-governmental ASOS programme [17].

Limitations and barriers in health promotion activities for older people in the voluntary sector

The list of the main problems/barriers for NGOs active in the field of health promotion for older people, largely based on the pilot research interviews and supported by the literature review [13-15, 18], is long. It includes:

- the lack of financial resource stability but also the lack of effective fundraising strategies;

- the lack of human resources and human resource management skills (difficulties in acquiring new members and volunteers, deficits in volunteer recruitment strategies);

- the lack of cooperation or formulation of a coherent position on a partnership basis within the sector;

- the lack of public governance oriented towards horizontal (and not only vertical) cooperation between sectors [19];

- difficulties managing delegated tasks - drastically insufficient financing for the employment of managerial staff, excessive bureaucratic burdens, compli- cated administrative work, very short deadlines for amendments, a problematic financing timetable (public task performance subsidies are supposed to serve for a calendar year), the obligation for a significant self-contribution (from 10 to $30 \%$ of the entirety of the programme value, considering the fact that financial capital is what the voluntary sector is not supposed to offer);

- the lack of legal regulations for Universities of the Third Age concerning quality assurance;

- the lack of sufficient information and promotion of NGO activities, especially in the local media, resulting in an idealised and burdensome public perception of volunteering activities (NGOs are perceived as large philanthropic institutions; work in NGOs should not be payed) and some degree of social distrust of the financial operations of NGOs;

- problems with older people's attitudes - elderly people often are pretentious and unappreciative of NGOs activities and distrust volunteers and NGOs as suspicious and maybe even scams.

\subsection{Health Promotion for Older People in the health sector}

\section{Role of the health sector in health promotion for older people}

The general rule of Polish Constitution states that the whole population should receive the same access to health services - the scope and type of services cannot differ based on the territory of the country. Obviously there are specific needs in some local areas and those needs may be satisfied without infringement of the rule mentioned above. Requirements on educational and prophylactic activities at the primary care level concern proper health needs identification and should implement existing programmes (elaborated by a public body). Such activities include, among others, prophylaxis of cardiovascular diseases, oncological problems, osteoporosis, family stress and conflicts, and violence. All the mentioned areas concern the older population and should be undertaken adequately to the indicated health needs and health status - on the basis of available epidemiological data or the health needs maps that are now being introduced into the system.

Since 1 January 2015, on the basis of the systemic legislation amendment of the Law on Health care services financed from public sources, the NFZ may elaborate, implement, realise and finance services other than the strictly medical or therapeutic which serve the whole population or a particular group of beneficiaries. Keeping in mind the WHO strategies, ${ }^{19}$ as well as the basic Polish regulations on the matter - the ordinances of the NFZ President, ${ }^{20}$ the proper place for health promotion programmes would be primary care mostly provided by individual doctors' practices or so-called $\mathrm{NZOZ}$ - non-public health care units. According to the NFZ report current primary care potential in different regions differs quite significantly, mainly in the spheres of placement, organisation and scope of activity - the subjective complexity of contracts; providers' potential 
concentration have to be underlined particularly [20]. Such situations, in the view of the NFZ, result from the "petrified" first Sickness Funds contracts that became so persistent - despite the process of unification of contracts, methods and levels of primary care health service financing. This seems to have also had a decisive impact on health promotion because the basic legal act on health care services financed from public funds, which indicates the type of services included into the guaranteed health services basket, ${ }^{21}$ does not explicitly use the term of health promotion, not to mention health promotion for older people.

\section{Cooperation of health providers with other sectors}

Different forms of cooperation may be indicated based on the National Health Programme that constitutes a foundation for detailed health promotion programmes. Health promotion programmes are mainly implemented in health sector institutions with primary care providers as the point of first contact. In this context the cooperation between the primary care unit and medical professionals, such as community nurses and midwives (often employed as people responsible for health promotion - health promoters - in the primary care unit), is crucial for the success of the programme. This primarily regards doctors, nurses and other professional personnel of primary care (specialists, ambulatories, psychological health units, educational institutions, social assistance centres, local administration and territorial governments as well as other sites and professionals acting in a given territory are also mentioned).

The next type of inter-sectorial cooperation concerns local social involvement. This focuses on the activation of the local population and its representatives: associations, community bodies and organs, NGO's acting locally, Koła Gospodyń Wiejskich (popular social clubs for women living in the country) and local volunteer fire brigades. Such cooperation includes varied activities: organisation of educational and cultural events focused on health promotion issues, discussion meetings (at schools, kindergartens, cultural centres or clubs in the suburbs), individual contact with doctors and nurses, psychologists, community nurses, social workers and other professionals devoted to health advisory and concentrated on health risk prevention and enabling citizens' contact with health providers, medical practices and specialists.

\section{Financing health promotion services in the health} sector

Primary health providers deliver health care services on the basis of general provisions and contracts with the National Health Fund. From the very beginning of the systemic reforms, health promotion was planned to be included in the package of primary care main liabilities [22]. The legislation, however, does not directly indicate particular services, but it constitutes a legal basis for the executive regulations of the Ministry of Health called the "basket regulations." Subsequently, these provisions are concretely specified in particular contracts with the National Health Fund, acting as a public payer.

\section{Examples of health sector activities in health pro- motion for older people}

Regarding the health sector, and specifically primary care units, the indication of good practices is really difficult due to the extremely limited programmes of health promotion which are addressed directly to the older population. Among the programmes offered by the Ministry of Health which crucially concern the scope of primary care liabilities and are focused on the population $65+$, especially important is the National Programme for fighting oncological diseases and its subsidiary, the Programme of Early Detection of Breast Cancer - addressed at women 50-69. The programme's nature relates more to intervention but it encompasses different activities concerning prevention, like educational and informative actions. Due to the introduction of new legislation concerning oncological patients in 2015, new obligations were assigned to primary care.

Since 2011, the National Programme for civilisation diseases (overweight, obesity, cardiovascular diseases, cancers and diabetes) has been being implemented. Among its different components, two concern health promotion activities: Module I: the Programme for the prevention of obesity and chronic non-communicable diseases by means of nursing improvement and physical activity (POL-HEALTH), and Module II: the Programme for prevention and treatment of Diabetes in Poland. The ministry of Health also introduced the Programme for early prevention of genitourinary cancers among men aged $45+$. Every mentioned programme has to be realised with the engagement of primary care.

Since 2012, a new medical procedure has been included in the health sector: complex geriatric evaluation (COG). It is provided for hospital patients but also has the potential to influence further treatment at the primary care level. Due to COG, the knowledge of patients' needs and states should be improved and also health promotion addressed in later stages should have better effects.

Nevertheless, the role of primary care should be considered crucial in light of the approach presented by the Interdisciplinary School of Health Promotion for Seniors [23]: primary care doctors and nurses are the best individuals to manage coordination of different initiatives in this context and the primary care unit is the most adequate site for action. One may fully agree that the initiatives and activities of health promotion are possible only due to the personal motivation, engagement and professional experience of key actors and funders. It is also true that the sustainability of health promotion projects depends on this. "The Golden Age" programme in Krakow (mentioned earlier) may be presented as an example of a programme related to primary care in regard to health promotion for older people. It is addressed to physicians and nurses, not to older persons themselves (it offers special trainings for professionals).

Limitations and barriers in health sector involvement in health promotion programmes for older people

The pilot research performed in Poland and the literature review helped to identify the main limitations and 
barriers concerning health sector involvement in health promotion for older people, with a focus on primary care problems. Despite the very basic problem, a generally low level of financing for health promotion services, the following obstacles should be mentioned as barriers and limitations:

- the lack of qualified medical personnel ${ }^{22}$ - doctors and nurses are not qualified in some areas (dietary advice, adequately proposed physical activities to respond to specific problems, assisted and motivated lifestyle change);

- the lack of time for educational and advisory visits (medical doctors often underline that they have no time for health promotion services because they do not have enough time for medical treatment in cases of illness);

- the lack of well prepared and competent health educators - doctors and nurses do not have to be involved in all health promotion activities. The necessity for introduction of health educator positions may be justified economically [24] due to arguments concerning optimisation of health care expenditures [25] and the obvious potential benefits for patients [27]. But also the nature of health education justifies this necessity. The WHO defines health education as reasonable education possibilities including different communication forms which should be created with the aim of improving understanding and using knowledge to improve individual and population health [28, 29];

- unclear rules for payment for health promotion services (no payment in reality);

- the dominating stereotype in relation to the population over 65 - that it is too late for health promotion to face many health problems which exist at this stage, such that regular checks of medical parameters and subsequent medical treatment has to prevail; such a strictly medical approach results from the model of medical doctors' education, focused on diseases, diagnoses and treatment, but rarely including a wider perspective.

\section{Conclusions and recommendations}

Since 1989, different reform activities were also focused on decentralisation in the health area. Much of the authority over the health sector was transferred from the central level (the Ministry of Health and other health related governmental agencies) down to the regional and local level (voivodships, counties and municipalities). Publicly owned health facilities were given autonomy and a significant number of them, especially outpatient care units, have been privatized. The system of tax-based financing of health care was replaced by a quasi-insurance system with new payment mechanisms for health care providers. Moreover, the system was opened to grassroots initiatives and hundreds of voluntary entities called public benefit organisations in Poland were established.

The general systemic reforms in the state system, the economy and in the health sector affected the sphere of public health as well. The recovered autonomy and freedom of territorial self-government entities, as well as private non-profit initiatives, resulted in thousands of new programmes and services in health promotion and disease prevention. However, the abundance of (often very interesting) new programmes, projects and actions which are frequently directly related to health promotion, does not wholly alleviate the ills of the new reality. Institutions promoting and developing modern (i.e. efficient and effective) health promotion encounter numerous obstacles, such as the limited ability to coordinate cross-sectoral cooperation, low funding for research and practical activity and, last but not least, similarly to many other countries, still a relatively low degree of health awareness among the general public and limited interest in public health among health care providers.

As our research shows, the lack of coordination between decentralised institutions seems to be the crucial problem in general, but especially in the sphere of health promotion interventions for older people. As in other countries, health promotion and health education are grouped primarily, but not exclusively, within the health care system. Therefore, most legislative regulations concerning them are acts adopted in the area of health care. And this is despite the fact that Article 3 of the Law on public health mentions that the tasks of public health are to be carried out, in cross-sectoral cooperation, by government bodies, state entities including executive agencies, National Health Fund units and local government bodies carrying out their own mandatory tasks in health prevention or health promotion. Additionally, tasks in the field of public health can also be undertaken by entities whose statutory objectives or activities concern matters included in the public health tasks, i.e.by churches and religious associations, social cooperatives or local government bodies' cooperatives.

The diversity of organisations performing different tasks makes it challenging to identify the real sources of funding for health promotion. The abundance of entities is accompanied by a variety of potential sources of funding, both public and private, with financial flows that are equally diverse. Public funds go not only to public institutions but also, through grants and subsidies, to private entities performing tasks related to health promotion, education, and preventive health care. Public institutions in turn benefit on a large scale from the financial aid of private benefactors. At the central government (macro) level, the Polish statistics show only aggregated numbers - expenditures for public health and prevention. There are no separate aggregated data on expenditures for health promotion activities, not to mention data on funding health promotion for older people. Hence, more insight into funding health promotion for older people can be provided by identifying concrete programmes in different sectors by different institutions and organisations and showing their funding sources and used mechanisms.

In Poland, three sectors seem to play a major role in providing health promotion interventions for older people: the sector of local governments and municipalities, the voluntary sector and the health sector. In all these 
sectors we can identify very interesting programmes and activities. Some of them have been mentioned. Unfortunately it is still a great challenge to bring institutions from different sectors around one table to develop coordinated and coherent strategies and programmes in health promotion, even if they are obliged to cooperate. The territorial and local government plays a crucial role in developing community health promotion and prevention programmes (impact raising public awareness in the field of "healthy ageing," the promotion of a healthy lifestyle, etc.) and it is very often the creator of education activities for older people but it needs health providers and NGOs for implementation of its ideas. However, many NGOs (including the Manko Association and the Universities of the Third Age mentioned above) often concentrate their activities more on "active ageing" for healthier and privileged people and not directly on "healthy ageing" for people with health problems. Of course, physical and intellectual activity reduce the risks for older people and the prevalence of different diseases, but what we need is also the direct prevention of diseases and the promotion of healthy lifestyle directed at unhealthier groups.

Also the cooperation and coordination between the different levels of territorial self-government, and territorial self-governments and the central government seem to be very weak. Taking into account the scarcity of the real and financial resources on one side and the large number of different initiatives carried out by diverse organisations (state, territorial administration, health care providers, etc.) on the other, there is no need for more separate actions and programmes in the field of health promotion for older people in Poland. What is needed is the identification of extreme over- and under-provision of fields with health promotion services and better coordination of different programmes and activities. The precondition to achieve this is the implementation of evidence-based coordination institutions and mechanisms which are able to bring together all the stakeholders who are active in the sphere of health promotion/health promotion for older people. Also a comprehensive database of all programmes and activities aimed at improving the socioeconomic and health status of the elderly implemented in Poland by diverse organisations is needed. While there are few self-government associations oriented towards improving cooperation and experience exchange in this field, there is a need for greater coordination and information exchange of plans and financial possibilities.

The lack of financial resources and intra- as well cross-sectoral cooperation are not the only significant barriers to developing effective and efficient health promotion programmes for older people. Especially in the health sector, there is a dominant stereotype that for the population over 65 that faces many health problems, it is a bit too late for health promotion and medical treatment has to prevail. The first comprehensive activities in health promotion for older people have been taken only very lately. And even now the majority of policy makers and decision makers in the health sector are concentrating their attention on health problems and disease prevention for younger people.
Another limitation identified in all the sectors is the lack of human resources (e.g. competent health educators) and human resource management as well as the communication skills needed for developing and implementing successful projects. The voluntary sector also makes claims about excessive bureaucratic burdens, complicated administrative procedures, short deadlines for amendments, a problematic financing timetable and problems with obligatory financial self-contribution. As was indicated in interviews with voluntary sector practitioners, there is also a problem with the attitudes of older people: elderly people distrust volunteers, they are more pretentious and are not ready to change their lifestyle or diet or they are not even willing to participate in the programmes offered by public institutions.

Bearing in mind all the limitations, barriers and problems in planning, financing and implementing health promotion activities for older people, provided by both public and private institutions, the situation seems to be challenging and difficult. As a middle developed country in transition, Poland cannot spend the same amount of money and devote the same real resources to health care in general and health promotion in particular as more wealthy Western European countries. On the other hand, the growing number of initiatives, both public (the central government, territorial self-governments, other public institutions such as the NFZ) and private (NGOs, Universities of the Third Age, foundations) have provided us with some hope for future development. A new impulse for developing and fostering health promotion ideas is expected to come from the new Law on Public Health adopted in 2015 that lists, among other things, health promotion as an important public task and, to some extent, defines the responsibilities of public and private institutions for health promotion.

In view of the large number of widely dispersed programmes, it is necessary to integrate selected local public health programmes to achieve better results and improve their cost-effectiveness. A necessary condition to improve the effective use of resources is also the implementation of a system for monitoring and evaluating national and local programmes and their effects. Without the introduction of mandatory, comprehensive cost-effectiveness analysis and quality control instruments, it will not be possible to identify the best practices and subsequently eliminate or modify programmes which are not costeffective. Building a publicly accessible database of best practices to address selected problem areas, with examples of policies that have a proven record of efficiency, could also facilitate health promotion actions.

Nevertheless, a stable source of financing of health promotion programmes for the elderly is needed. This is especially important for local government units, which often face budget deficits, and for the voluntary sector. Public Benefit Organisations financing and public service contracting rules should be arranged in a more sustainable way which allows reasonable prospective annual budgeting. Contracting public services to PBOs should also be less reliant on PBOs self-contributions. Also, new instruments triggering positive incentives for intensifica- 
tion of health promotion activities in the health sector are needed as the existing methods of payment for health services do not correspond with the idea of health promotion service delivery at primary care units.

Last but not least, even if we provide older people with the best and most effective health promotion services, we cannot prevent the fact that their health status will be poorer than the health status of the younger population. The comprehensive conception of "healthy and active ageing" should accept this by proposing solutions which fully integrate older, unhealthy and disabled people in social life.

\section{Notes}

${ }^{1}$ The ratio between the number of persons aged 65 and over (age when they are generally economically inactive) and the number of persons aged between 15 and 64 . The value is expressed per 100 persons of working age (15-64).

${ }^{2}$ This includes the 66 urban municipalities (big cities) with a special status whereby they have responsibilities usually exer-cised by counties.

${ }^{3}$ Swiss Contribution and WWPE (2016), Realizacja projektów w ramach Szwajcarsko-Polskiego Programu Współpracy - Wytyczne dla beneficjentów Priorytetu nr 1 i nr 2, http://cppc. gov.pl/be2/files/documents/Szwajcar/SPPW_Wytyczne_dla_ IR_wersjazatw_21.02.2012.pdf; accessed: 02.04.2016.

${ }^{4}$ Marshal Office acts as the subsidiary body of the Board of Voivodship and the Marshal of voiwodship.

${ }^{5} \mathrm{http} / / / w w w . s s d . o p o l s k i e . p l / p a g e / 22$,zlota-jesien.html; accessed: 07.04.2016.

${ }^{6}$ Molnár Györffyné [8], www.zze-freiburg.de/assets/pdf/ Toolbox-of-tested-solutions-Active-Ageing.pdf; accessed: 08.04.2016.

${ }^{7}$ www.dlaseniora.krakow.pl; accessed: 08.04.2016.

${ }^{8}$ The total budget of the project is approx. PLN 1.5 million and the municipality's own fund is nearly PLN 300 thousand. The project ran from May 2015 till April 2016.

${ }_{9}^{9}$ MRPiPS, https://www.mpips.gov.pl/seniorzyaktywnestarzenie/rzadowy-programme-asos/; accessed: 08.04.2016.

${ }^{10} \mathrm{MRPiPS}, \mathrm{http}: / /$ senior.gov.pl/programme_senior_wigor; accessed: 08.04.2016.

${ }^{11}$ http://bazy.ngo.pl/; accessed: 08.04.2016.

${ }^{12} \mathrm{http}: / /$ www.mpips.gov.pl/bip/wykaz-organizacji-pozytkupublicznego/; accessed: 08.04.2016.

${ }^{13} \mathrm{http}: / /$ bazy.ngo.pl/, http://www.mpips.gov.pl/bip/wykazorganizacji-pozytku-publicznego/; accessed: 08.04.2016.

${ }^{14}$ Previous Ministry of Labour and Social Policy.

${ }^{15}$ Stowarzyszenie MANKO, http://stowarzyszeniemanko. pl/; accessed: 08.04.2016.

${ }^{16}$ Glos Seniora/Serwis Nowoczesnego Seniora, http://glosseniora.pl/; accessed: 08.04.2016.

${ }^{17}$ Karta Seniora - Zniżki Dla Seniorów, http://glosseniora. pl/seniorcard; accessed: 08.04.2016.

${ }^{18}$ Forum 50+ Seniorzy XXI Wieku, http://www.forum50. org/; accessed: 08.04.2016.

${ }^{19}$ E.g.: WHO Global Strategy for Health for All by the Year 2000 [21].

${ }^{20}$ DecreeNr 85/2011/DSOZ of the National Health Fund President from 17 November on the conditions for arrange- ments and realisation of contracts for health service delivery: primary care type (www.nfz.gov.pl/new/?katnr_3\&dzialnr+12 \&srtnr+4688; accessed: July 2015); Decree Nr 98/2012/DSOZ of the National Health Fund President from 21 January 2012 on the conditions for arrangements and realisation of contracts for health service delivery: Prophylaxis health programmes.

${ }^{21}$ Ministry of health regulation on guaranteed primary care health services dated 24 September 2013; The list of guaranteed primary care health services and realisation conditions, Attachment no 1 to the Ministry of health regulation on guaranteed pri-mary care health services from 24 September 2013.

${ }_{22}$ The lack of qualified medical professionals also stifles other public health activities [26].

\section{References}

1. Sagan A. et al., Poland: Health system review, "Health Systems in Transition" 2011; 13 (8), European Observatory on Health Systems and Policies, Copenhagen.

2. GUS (Central Statistical Office), Zdrowie $i$ zachowania zdrowotne mieszkańców Polski w świetle badania EHIS 2014, Główny Urząd Statystyczny, Warszawa 2015, http:// stat.gov.pl/obszary-tematyczne/zdrowie/zdrowie/zdrowie-i-zachowania-zdrowotne-mieszkancow-polski-w-swietle-badania-ehis-2014,10,1.html; accessed: 02.04.2016.

3. Mossakowska M., Więcek A., Błędowski P., POLSENIOR. Aspekty medyczne, psychologiczne, socjologiczne i ekonomiczne starzenia się ludzi w Polsce, Termedia Wydawnictwo Medyczne, Poznań 2012.

4. GUS (Central Statistical Office), Stan zdrowia ludności Polski w 2009 r., Główny Urząd Statystyczny, Warszawa 2011.

5. NFZ (Narodowy Fundusz Zdrowia), Sprawozdanie z dziatalności Narodowego Funduszu Zdrowia za 2015 rok, Narodowy Fundusz Zdrowia, Warszawa $2016 \mathrm{~b}$.

6. GUS (Central Statistical Office), Zdrowie i ochrona zdrowia $w 2014$ r., Główny Urząd Statystyczny, Warszawa 2015, http://stat.gov.pl/obszary-tematyczne/zdrowie/zdrowie/zdrowie-i-ochrona-zdrowia-w-2014-r-,1,5.html; accessed: 02.05.2016.

7. Golinowska S., Decentralizacja i polityka społeczna. Siła, stabość czy niedostosowanie? Próba oceny, "Polityka Społeczna", numer tematyczny 2015; 1: 2-10.

8. Molnár Györffyné I. et al., Active Aging, Quality aging in an urban environment, Toolbox of tested solutions promoting active ageing at local level, 2011, www.zze-freiburg. de/assets/pdf/Toolbox-of-tested-solutions-Active-Ageing. pdf; accessed: 08.04.2016.

9. CBOS (Centrum Badania Opinii Społecznej), Aktywność społeczna Polaków, Fundacja Centrum Badania Opinii Społecznej, Warszawa 2014, http://www.cbos.pl/SPISKOM. POL/2014/K_060_14.PDF; accessed: 08.05.2016.

10. Klimczuk A., Kierunki rozwoju uniwersytetów trzeciego wieku w Polsce, "E-Mentor, Dwumiesięcznik SGH" 2013; 4 (51), http://www.e-mentor.edu.pl/artykul/index/numer/51/ id/1048; accessed: 10.04.2016.

11. Gibalska A., Przeglad źródet Finansowania Uniwersytetów Trzeciego Wieku, Fundacja dla Uniwersytetu Jagiellońskiego, Kraków 2011, http://orka.sejm.gov.pl/WydBAS.nsf/0/ddb3 582fea69f634c12572d60046c380/\$FILE/Przegl\%C4\%85d 
$\% 20 \% \mathrm{C} 5 \% \mathrm{BAr} \% \mathrm{C} 3 \% \mathrm{~B} 3 \mathrm{de} \% \mathrm{C} 5 \% 82 \% 20$ finansowania $\%$ 20uniwersytet $\% \mathrm{C} 3 \% \mathrm{~B} 3 \mathrm{w} \% 20$ trzeciego $\% 20$ wieku.pdf; accessed: 10.04 .2016 .

12. Janik-Komar J., Rola kościoła $w$ aktywizacji osób starszych, "Rocznik Andragogiczny" 2009; R, http://cejsh.icm. edu.pl/cejsh/element/bwmeta1.element.db462422-f8653d46-ae4a-c9fe0f81a724; accessed: 10.04.2016.

13. Adamiak P., Zaangażowanie społeczne Polek i Polaków. Wolontariat, filantropia, $1 \%$ i wizerunek organizacji pozarzqdowych. Raport z badania 2013, Stowarzyszenie Kon/Jawor, Warszawa 2014, http://www.malopolskie.pl/ Pliki/2015/20140407_RAPORT_final-1.pdf; accessed: 10.04.2016

14. Adamiak P., Charycka B., Gumkowska M., Polskie Organizacje Pozarzadowe, Stowarzyszenie Kon/Jawor, Warszawa 2015, http://www.kson.pl/attachments/article/1436/PolskieOrganizacje2015.pdf; accessed: 12.04.2016.

15. Przewłocka J., Adamiak P., Herbst J., Podstawowe fakty o organizacjach pozarzqdowych. Raport z badania 2012, Stowarzyszenie Kon/Jawor, Warszawa 2013, http://www. ngo.pl/PodstawoweFakty_2012_raport/ebook/content/ PodstawoweFaktyNGO_2012_KlonJawor_raport.pdf; accessed: 12.04.2016.

16. Woźniak B., Tobiasz-Adamczyk B., Brzyska M., Promocja zdrowia wśród osób starszych $w$ Polsce $w$ świetle badań przeprowadzonych $w$ projekcie healthPROelderly - wypracowanie opartego na faktach przewodnika dotyczqcego promocji zdrowia wśród osób starszych, "Problemy Higieny i Epidemiologii” 2009; 90 (4): 459-464.

17. ProEthica, Jesteś wyjątkowq różq. Indywidualne podejście w pracy z osobami starszymi, 2015, http://proethica.pl/ wordpress/wp-content/uploads/2015/12/model-personalizacji-szkic_IT-1.pdf; accessed: accessed: 14.04.2016.

18. Adamiak P., Charycka B., Gumkowska M., Wizerunek Organizacji Pozarzadowych. Raport z badania 2015, Stowarzyszenie Kon/Jawor, Warszawa 2015, http://www. malopolskie.pl/Pliki/2015/raport_wizerunek.pdf; accessed: 14.04.2016.

19. Olech A., Między zainteresowaniem a zaangażowaniem aktywność obywatelska i organizacje pozarzqdowe $w$ Polsce, “Analizy i Opinie” 2014, nr specjalny 7: Decydujmy razem, Instytut Spraw Publicznych, http://www.isp.org.pl/ uploads/analyses/834940208.pdf; accessed: 16.04.2016.

20. NFZ (Narodowy Fundusz Zdrowia), Podstawowa Opieka Zdrowotna, potencjat i jego wykorzystanie z załacznikiem European Observatory on Health Systems and Policies, Podstawowa Opieka Zdrowotna i profilaktyka w podstawowej opiece zdrowotnej $w$ Europie (Primary care, potential and its use with attachment of the European Observatory on Health Systems and Policies: Primary care and prophylaxis in primary care in Europe), Narodowy Fundusz Zdrowia, Warszawa 2016, www.nfz.gov.pl/.../gfx/.../poz_potencjal_i_jego_wykorzystanie.pdf; accessed: 08.09.2016.

21. WHO, Global Strategy for Health for All by the Year 2000, World Health Organization, Geneva 1981, http://apps. who.int/iris/bitstream/10665/38893/1/9241800038.pdf; accessed: 08.09.2016.

22. COiEOZ (Centrum Organizacji i Ekonomiki Ochrony Zdrowia), Kontraktowanie świadczeń promocji zdrowia w podstawowej opiece zdrowotnej. Projekt, "Biuletyn Informacyjny" 1997; 27.

23. Szymborski J., Iwińska K., Przewoźniak K., Błaszczyk K., Troszyński M., Szylar A., Interdyscyplinarna Szkoła Promocji Zdrowia Seniorów, Collegium Civitas Press, Warszawa 2014.

24. Wolf S., Husten C., Lewin L., Marks J., Fielding J., Sanchez E., The Economic Argument for Disease Prevention: Distinguishing Between Value and Savings. A Prevention Policy Paper Commissioned by Partnership for Prevention, February 2009, https://www.prevent.org/data/ files/initiatives/economicargumentfordiseaseprevention. pdf; accessed: 08.07.2016.

25. Baranowski J., Windak A., Optymalizacja polskiego systemu finansowania Podstawowej Opieki Zdrowotnej, Ernst \& Young, Warszawa 2012.

26. Cianciara D., Piotrowicz M., Tucka-Dorociak H., Zasoby kadrowe zdrowia publicznego i promocji zdrowia w Polsce. Cz II. Oferty pracy, "Problemy Higieny i Epidemiologii" 2010; 91 (3): 475-481.

27. Rezner A., Rezner W., Kosecka J., Edukator zdrowia $w$ podstawowej opiece zdrowotnej jako szansa na podniesienie poziomu promocji zdrowia i profilaktyki w Polsce (Health educator in primary care setting - an opportunity for the improvement of health promotion and prophilaxis in Poland), "Problemy Higieny i Epidemiologii" 2013; 94 (3): 407-412.

28. WHO, List of Basic Terms. Health Promotion Glossary, World Health Organization, Geneva 1998.

29. Gold S., Miner R., Reports on the Joint Committee on Health Education and Promotion Terminology, "American Journal of Health Education" 2001; 32 (2): 89-103.

\section{Internet data bases and internet payes}

1. Alzheimer Europe: http://www.alzheimer-europe.org/ Policy-in-Practice2/Country-comparisons/The-prevalenceof-dementia-in-Europe/Poland

2. bazy.ngo.pl - Baza danych organizacji pozarządowych i instytucji, http://bazy.ngo.pl/

3. Eurostat: http://ec.europa.eu/eurostat/data/database

4. EU-SILC data (EuphaEuropean health for all database, HFA-DB), WHO Regional Office for Europe: http://data. euro.who.int/hfadb/

5. EU-SILCdata: http://ec.europa.eu/eurostat/data/database

6. forum50+ Seniorzy XXI wieku, http://www.forum50.org/

7. Głos Seniora/Serwis Nowoczesnego Seniora, http://glosseniora.pl/

8. http://eeagrants.org

9. http://www.ssd.opolskie.pl/page/22,zlota-jesien.html

10. Karta Seniora - Zniżki dla Seniorów', http://glosseniora.pl/ seniorcard

11. MRPiPS (Ministerstwo Rodziny, Pracy i Polityki Społecznej), Rządowy Program ASOS, https://www.mpips. gov.pl/seniorzyaktywne-starzenie/rzadowy-program-asos/

12. MRPiPS (Ministerstwo Rodziny, Pracy i Polityki Społecznej), http://senior.gov.pl/program_senior_wigor

13. NFZ, Programy profilaktyczne, http://nfz.gov.pl/dlapacjenta/programy-profilaktyczne/ 
14. OECD Health Statistics, http://stats.oecd.org/index. aspx?DataSetCode=HEALTH_STAT\#

15. Stowarzyszenie Manko, http://stowarzyszeniemanko.pl/

16. Swiss Contribution and WWPE, Realizacja projektów w ramach Szwajcarsko-Polskiego Programu Współpracy Wytyczne dla beneficjentów Priorytetu $\mathrm{nr} 1 \mathrm{i} \mathrm{nr}$ 2, http:// cppc.gov.pl/be2/files/documents/Szwajcar/SPPW_Wytyczne_dla_IR_wersjazatw_21.02.2012.pdf
17. Wykaz organizacji pożytku publicznego uprawnionych do otrzymania $1 \%$ podatku dochodowego od osób fizycznych za rok 2014, http://www.mpips.gov.pl/bip/wykaz-organizacji-pozytku-publicznego/

18. www.aotm.gov.pl

19. www.dlaseniora.krakow.pl 